\title{
Miasto na prawach powiatu w kontekście administracyjnego postępowania egzekucyjnego
}

\# miasto na prawach powiatu \# postępowanie egzekucyjne w administracji \# egzekucja obowiązków pieniężnych

\# city under the law of county \# enforcement proceedings in administration \# execution of monetary obligations

Miasto na prawach powiatu jako szczególna jednostka samorządu terytorialnego została obdarzona w egzekucyjnym postępowaniu administracyjnym wyjątkową kompetencją, jaka nie przysługuje żadnej innej gminie czy powiatowi. Nietypowość ta przejawia się w możliwości zajmowania pozycji organu egzekucyjnego obowiązków o charakterze pieniężnym konkretyzowanych przez miasto na prawach powiatu, a w zasadzie jego organ wykonawczy. W takiej sytuacji nie ma potrzeby korzystania z pomocy naczelnika urzędu skarbowego jako organu wykonawczego o kompetencji ogólnej, który doprowadza do przymusowego uiszczenia należności pieniężnych wszystkich pozostałych gmin. Wspomnieć należy również pozostałe role procesowe, jakie przyjmować może interesujący nas podmiot, tj. wierzyciela, organu rekwizycyjnego, dłużnika zajętej wierzytelności czy nawet zobowiązanego, aczkolwiek nie stanowią one differentia specifica miasta na prawach powiatu w kontekście administracyjnego postępowania egzekucyjnego i nie wypada poświęcać im nadmiernej uwagi.

A city under the law of county as a special unit of territorial self-government has been endowed with an exceptional administrative competence in an administrative procedure that is not vested in any other municipality or poviat. This extraordinary character manifests itself in the ability to occupy the position of the enforcement body of pecuniary obligations determined by the city with under the law of county, and in principle its executive body. In this situation, there is no need to use the assistance of the head of the tax office as an executive body with general competence, which leads to the compulsory payment of all other municipalities' financial

Miasto. Pamięć i Przyszłość 3/2 (2018) ISSN 2543-621X

\section{OPEN ACCESS}

Citation: Bródka A., Miasto na prawach powiatu w kontekście administracyjnego postępowania egzekucyjnego, "Miasto. Pamięć i Przyszłość", $3 / 2$ (2018).

https://doi.org/10.26774/mpp.79

Editor: Jerzy Korczak

Received: October, 2018

Accepted: December, 2018

Published: December, 2018

Copyright: @ Ośrodek „Pamięć i Przyszłość" This is an open access article distributed under the terms of the Creative Commons Attribution-ShareAlike Licence, which permits unrestricted use, distribution, and reproduction in any medium, provided the original author and source are credited, with indications if any changes are made. All derivative works must be licensed under the same licence. 
claims. We should also mention the other procedural roles that may be taken by the entity we are interested in, ie the creditor, the requisitioning authority, the debtor of the debt or even the debtor, although they do not constitute a differentia specifica of the poviat in the context of administrative enforcement proceedings and it is not appropriate to pay excessive attention to them.

mgr Adam Bródka - doktorant w Zakładzie Postępowania Administracyjnego i Sądownictwa Administracyjnego w Instytucie Nauk Administracyjnych na Wydziale Prawa, Administracji i Ekonomii Uniwersytetu Wrocławskiego. 


\section{Wprowadzenie}

Miasto na prawach powiatu, będące jednostką samorządu terytorialnego (a tak naprawdę reprezentujące je organy), odgrywa istotną rolę $w$ sprawowaniu administracji publicznej. Funkcjonowanie tego podmiotu nierozerwanie wiąże się z administracyjnym prawem procesowym jako narzędziem realizacji wielu przydanych przez przepisy prawa zadań. Nie chodzi tu wyłącznie o stosowanie prawa w postaci tworzenia norm indywidualnych i konkretnych za pośrednictwem decyzji administracyjnych - należy również pamiętać o procedurze przymusowego wykonywania takich norm (aczkolwiek wyłącznie tych o charakterze zobowiązującym). W porządku prawnym występują ponadto obowiązki statuowane przez przepisy samego prawa, które nie wymagają sprowadzenia do postaci jednostkowej, a czuwanie nad ich realizacją również wchodzi w zakres zadań jednostek samorządu terytorialnego. Pojawia się więc konieczność dysponowania odpowiednimi środkami przez miasto na prawach powiatu, za pomocą których nakazy i zakazy prawa znajdą swoje odbicie w rzeczywistości. Tu z pomocą przychodzi postępowanie egzekucyjne w administracji stanowiące niekiedy jedyne remedium na problem niewykonania obowiązku o charakterze publicznoprawnym. Pozycja miasta na prawach powiatu kształtuje się w tejże procedurze w sposób zróżnicowany, w niektórych momentach nie odbiegając od pozycji każdego innego organu administracji publicznej, a w innych, z uwagi na nietypową konstrukcję rzeczonego podmiotu, nadaje mu niestandardowe uprawnienia. Niniejszy tekst ma na celu przybliżenie i naświetlenie tego złożonego zagadnienia, zarówno z teoretycznoprawnego punktu widzenia, jak i nawiązując do praktycznych przykładów.

\section{Istota postępowania egzekucyjnego w administracji}

Wykonywanie administracji publicznej częstokroć wiąże się z nakładaniem obowiązków oraz czuwaniem nad ich realizacją, 
a w ostateczności nawet z ich przymusowym wykonaniem. Wynika to z samej natury administracji publicznej, której wyłącznym zadaniem jest realizowanie indywidualnych i zbiorowych potrzeb obywateli uwarunkowanych determinantami o charakterze społeczno-gospodarczym¹. Nie oznacza to jednak, iż administracja przydaje wyłącznie uprawnienia, gdyż równie ważne dla zbiorowości staje się precyzyjne wyznaczanie granic dopuszczalnego zachowania jednostek, ich grup, a niekiedy całego społeczeństwa. Organy administracji, czy to w znaczeniu ustrojowym czy funkcjonalnym, są uprawnione - a w większości przypadków nawet zobligowane - do precyzowania obowiązków w formie aktów administracyjnych (decyzji, postanowień). Ściśle ujęte nakazy lub zakazy określonego postępowania przyjmują zawsze charakter publicznoprawny - ich realizacja jest korzystna, a często niezbędna dla dobra interesu społecznego czy też publicznego. Wyraźnie należy jednak podkreślić, że źródłem obowiązków są także akty normatywne - ustawy, rozporządzenia, akty prawa miejscowego, gdzie obowiązki z nich wynikające występują ex lege i nie wymagają autorytatywnej konkretyzacji. Nota bene, akty normatywne tak naprawdę są źródłem wszystkich istniejących nakazów lub zakazów, przy czym część z nich, aby nadawała się do wykonania, musi zostać w pierwszej kolejności sprowadzona do postaci normy jednostkowej w procesie stosowania prawa.

1. Prawo administracyjne, red. J. Boć, Wrocław 2010, s. 15.

2. Z. Leoński, Egzekucja administracyjna świadczeń niepieniężnych, Warszawa 1968, s. 6.

3. Ustawa z dnia 17 czerwca 1966 r. o postępowaniu egzekucyjnym w administracji (Dz. U. z 2018 r. poz. 138, 398).

4. Wyrok NSA z dnia 26 marca 2009 r., II FSK 1462/08.
Z istoty obowiązku wynika konieczność wykonania jego treści. Na tym gruncie podmiot obciążony jest nakazem lub zakazem, jest w pełni związany, wykluczona zostaje więc możliwość jakiejkolwiek nim dyspozycji. Jakjuż podkreślono na początku tekstu, administracja publiczna nie tylko tworzy obowiązki, ale także bacznie kontroluje ich wykonanie, czyli powstanie w świecie rzeczywistym stanu odpowiadającego treści normy prawnej. W sytuacji, gdy podmiot zobligowany do podjęcia określonego działania, czy też zaniechania takiego działania, nie wypełni polecenia prawa w sposób dobrowolny, to na administracji publicznej zaczyna ciążyć konieczność podjęcia przymusowej realizacji obowiązku. Doprowadzenie do pełnej zgodności sytuacji faktycznej z obowiązującymi aktami prawnymi jest bowiem jednym z najważniejszych zadań administracji publicznej, z którego to nie byłaby się w stanie wywiązać bez posiadania odpowiednich narzędzi². Narzędzia te dostarcza egzekucja administracyjna podejmowana w ramach postępowania egzekucyjnego regulowanego przez ustawę o postępowaniu egzekucyjnym w administracji (zwanej dalej u.p.e.a.)³. Co istotne - egzekucja i postępowanie egzekucyjne nie są terminami tożsamymi, czemu znakomity wyraz dał wyrok NSA z dnia 26 marca 2009 r. ${ }^{4}$ uwidaczniający występujące dystynkcje. Zgodnie ze stanowiskiem sądu „egzekucyjne postępowanie w administracji to zorganizowany ciąg czynności procesowych podejmowanych przez organy egzekucyjne oraz inne podmioty w celu przymusowego wykonania obowiązków

Miasto. Pamięć i Przyszłość 3/2 (2018) ISSN 2543-621X 
objętych egzekucją administracyjną. Postępowanie egzekucyjne zostaje wszczynane prędzej niż egzekucja. Zastosowanie środków egzekucyjnych poprzedzone jest bowiem takimi czynnościami, jak przesłanie upomnienia zobowiązanemu, sporządzeniem przez wierzyciela tytułu wykonawczego, jak również badanie wstępne dopuszczalności egzekucji administracyjnej i wymogów tytułu egzekucyjnego przez organ egzekucyjny w trybie art. 29 u.p.e.a.

W administracyjnym postępowaniu egzekucyjnym, co do zasady, można wyróżnić więc trzy stadia: stadium poprzedzające wszczęcie egzekucji administracyjnej, stadium stosowania egzekucji oraz stadium następujące po przeprowadzeniu egzekucji. Egzekucja administracyjna jako część (stadium) postępowania egzekucyjnego odnosi się wyłącznie do stosowania konkretnych środków przymusu skierowanych na wykonanie obowiązku o charakterze pieniężnym lub niepieniężnym. Zasadnicza różnica pojawia się również na tle charakteru prawnego podejmowanych przez organ egzekucyjny (lub jego pracownika) czynności. W ramach egzekucji administracyjnej wykorzystywane są środki egzekucyjne, czyli zinstytucjonalizowane formy przymusu państwowego stosowane według ściśle określonej procedury, a skierowane bezpośrednio na wykonanie obowiązku prawnego5. Dla przykładu, przeszukanie osoby, odebranie pieniędzy, czy też przymus fizyczny, będące środkami egzekucyjnymi, to tzw. czynności materialno-techniczne, czyli działania faktyczne nietworzące nowej indywidualno-konkretnej

Miasto. Pamięć i Przyszłość 3/2 (2018) ISSN 2543-621X 67 normy prawnej ani też nienakierowane bezpośrednio na wywołanie bezpośrednio skutku prawnego ${ }^{6}$. Nie oznacza to jednak, że czynności materialno-techniczne nie mogą skutku prawnego wywołać. Dla zobrazowania można tu podać skuteczną egzekucję obowiązku, która powoduje ustanie stanu prawnego istnienia obowiązku, tj. w wyniku odebrania zobowiązanemu pieniędzy za pomocą środka egzekucyjnego i przekazania ich wierzycielowi wygasa obowiązek prawny?

\section{Miasto na prawach powiatu a struktura postępowania egzekucyjnego $\mathbf{w}$ administracji}

W celu umiejscowienia miasta na prawach powiatu w administracyjnym postępowaniu egzekucyjnym należy w pierwszej kolejności przyjrzeć się strukturze podmiotowej tegoż postępowaniu oraz odnieść się do samej konstrukcji prawnej miasta na prawach powiatu. Administracyjne postępowanie wykonawcze w swojej konstrukcji podmiotowej jest niezwykle rozbudowane i zasadniczo różni się od postępowania administracyjnego jurysdykcyjnego. Z istoty przymusowego wykonania obowiązku wywnioskujemy, iż występować tu muszą przynajmniej trzy podstawowe podmioty: po pierwsze, zobowiązany, czyli podmiot, na którym obowiązek ciąży, po wtóre, podmiot urzeczywistniający wykonanie obowiązku, czyli organ egzekucyjny, po trzecie, podmiot

5. E. Bojanowski, Wykonanie zastępcze w egzekucji administracyjnej, Warszawa 1975, s. 34.

6. System Prawa Administracyjnego, Prawne formy działania administracji, t. 5, red. R. Hauser, Z. Niewiadomski, A. Wróbel, Warszawa 2013, s. 46-47.

7. Tamże, s. 46, 47. 
uprawniony do żądania wykonania obowiązku, zwany wierzycielem. Odnotować trzeba, iż w wyniku rozwiązań zawartych w u.p.e.a. dotyczących wierzyciela i organu egzekucyjnego bardzo często występuje tożsamość tychże podmiotów, skutkująca bezprzedmiotowością części uprawnień i obowiązków wierzyciela lub organu egzekucyjnego (przecież organ będąc jednocześnie wierzycielem i organem egzekucyjnym nie będzie składał sam do siebie wniosku o wszczęcie postępowania egzekucyjnego). Ponadto w ramach postępowania egzekucyjnego mogą występować również inne, fakultatywne podmioty, takie jak: prokurator, Rzecznik Praw Obywatelskich, Rzecznik Praw Dziecka, organizacja społeczna oraz osoba trzecie broniąca swojego interesu faktycznego lub prawnego ${ }^{8}$. Nie można wykluczyć także pojawienia się tzw. uczestników postępowania egzekucyjnego w postaci: świadków, biegłego skarbowego, biegłego sądowego, dozorcy czy zarządcy nieruchomości ${ }^{9}$. Ustawa egzekucyjna odnosi się do każdego z przedstawionych powyżej podmiotów i uczestników, precyzyjnie wskazując jego rolę w procesie przymusowego wykonania obowiązku. Nie czyniąc w tym miejscu jeszcze głębszych rozważań, wypada jednak odmówić miastu na prawach powiatu (jego organom) pozycji uczestnika w postępowaniu egzekucyjnym, sprowadzając jego status głównie do roli wierzyciela lub organu egzekucyjnego, a w niektórych przypadkach nawet zobowiązanego.

8. B. Adamiak, J. Borkowski, Postępowanie administracyjne i sądowoadministracyjne, Warszawa 2017, s. 642-653.

9. Tamże, s. 654-656.

10. Ustawa z dnia 5 czerwca 1998 r. o samorządzie powiatowym (Dz. U. z 2018 r. poz. 995 z późn. zm.), zwana dalej u.s.p.
Miasto na prawach powiatu jest tworem wyjątkowym, o złożonej konstrukcji prawnej, łączącej w sobie elementy samorządu gminnego oraz samorządu powiatowego. Powołano go do życia w wyniku ostatnich, zasadniczych reform administracji publicznej związanych z rekonstrukcją samorządu terytorialnego. Charakter prawny miasta na prawach powiatu określa art. 92 ust. 2 ustawy o samorządzie powiatowym¹0, wyraźnie podkreślając, że mamy do czynienia z gminą wykonującą zadania powiatu na zasadach określonych w ustawie. Wykonywanie zadań powiatu oznacza poszerzenie zakresu działania takiej jednostki samorządu terytorialnego i w interesującym nas zakresie przydanie możliwości konkretyzacji i egzekucji obowiązków nie tylko związanych z zadaniami gminy, lecz także powiatu. Innymi słowy, miasto na prawach powiatu będzie mogło pełnić rolę wierzyciela oraz organu egzekucyjnego jako gmina i jako powiat. Sformułowanie takie wymaga jednak istotnego doprecyzowania: jednostka samorządu terytorialnego działa bowiem zawsze przez swoje organy - uchwałodawczy i wykonawczy. Zgodnie z art. 92. ust. 1 u.s.p., organami miasta na prawach powiatu są rada miasta oraz prezydent miasta. Poruszając zagadnienie pozycji miasta na prawach powiatu w postępowaniu egzekucyjnym, musimy wskazać tu na jego organ wykonawczy, czyli prezydenta miasta, gdyż to wyłącznie on może stać się wierzycielem lub organem egzekucyjnym. Jest to wynikiem ogólnej koncepcji funkcjonowania organu wykonawczego jednostki samorządu terytorialnego

Miasto. Pamięć i Przyszłość 3/2 (2018) ISSN 2543-621X 
oraz regulacji ustawy o postępowaniu egzekucyjnym w administracji. Prezydent miasta wykonuje kompetencje właściwe dla wójta (burmistrza), zarządu powiatu oraz starosty ${ }^{11}$. Niewątpliwie fakt ten znacząco pozszerza zakres spraw, w związku z którymi organ wykonawczy miasta na prawach powiatu może występować jako podmiot w postępowaniu egzekucyjnym.

\section{Prezydent miasta na prawach powiatu jako organ egzekucyjny obowiązków o charakterze pieniężnym}

Zgodnie z art. 1a. pkt. 7 u.p.e.a., organem egzekucyjnym jest organ uprawniony do stosowania w całości lub w części określonych w ustawie środków służących doprowadzeniu do wykonania przez zobowiązanych ich obowiązków o charakterze pieniężnym lub obowiązków o charakterze niepieniężnym oraz zabezpieczania wykonania tych obowiązków. Jednakże regulacja ta dopiero w zestawieniu z przepisami określającymi właściwość rzeczową oraz miejscową daje nam pełny obraz organu egzekucyjnego jako zasadniczego podmiotu postępowania administracyjnego wykonawczego.

U.p.e.a dokonuje podziału obowiązków na te o charakterze pieniężnym (związane z koniecznością uiszczenia określonej sumy pieniędzy na rzecz organu, np. z tytułu podatku czy kary administracyjnej) i niepieniężnym (polegające na wykonaniu określonego działania, zaprzestaniu działania czy znoszeniu określonego stanu rzeczy). Konsekwentnie prawodawca zróżnicował właściwość rzeczową organów prowadzących postępowanie egzekucyjne na organy egzekucyjne obowiązków pieniężnych i niepieniężnych. Ustawa nadaje pozycję "gospodarza" postępowania przymusowego naczelnikowi urzędu skarbowego, właściwemu organowi gminy o statusie miasta, wymienionemu w odrębnych przepisach oraz gminom wchodzącym w skład powiatu warszawskiego, przewodniczącemu organu orzekającego w sprawach o naruszenie dyscypliny finansów publicznych w pierwszej instancji, dyrektorowi oddziału Zakładu Ubezpieczeń Społecznych wyznaczonemu przez ministra właściwego do spraw finansów publicznych oraz dyrektorowi oddziału regionalnego Agencji Mienia Wojskowego. Przepis art. 19 u.p.e.a. nie tworzy zamkniętego katalogu organów egzekwujących należności pieniężne, wskazując wyraźnie w § 8 na możliwość nadania takiej funkcji innemu organowi na podstawie przepisów szczególnych. Każdy z tych organów upoważniony jest do egzekucji innej kategorii obowiązków pieniężnych, stosując przy tym zróżnicowane środki egzekucyjne wyraźnie wskazane przez ustawę.

Powracając meritum tekstu, prezydent miasta na prawach powiatu może pełnić funkcję organu egzekucyjnego jedynie na podstawie art. 19 § 2 u.p.e.a. Trzeba wyraźnie podkreślić, iż to właśnie ten przepis jest zasadniczą regulacją różnicującą pozycję miasta na prawach powiatu od pozostałych jednostek samorządu terytorialnego wadministracyjnym postępowaniu egzekucyjnym. Znaczna większość gmin nie posiada kompetencji do występowania w pozycji organu egzekucyjnego
Miasto. Pamięć i Przyszłość 3/2 (2018) ISSN 2543-621X
11. Prawo administracyjne, red. J. Boć, s. 214. 
ustalanych lub określanych i pobieranych przez siebie należności pieniężnych, zmuszone zostają więc do korzystania z „usług” naczelników urzędów skarbowych, co może odciskać wyraźne znamię na skuteczności egzekucji.

Stosownie do treści art. $19 \S 2$ u.p.e.a. właściwy organ gminy o statusie miasta wymienionej w odrębnych przepisach, a także gminy wchodzącej w skład powiatu warszawskiego jest organem egzekucyjnym uprawnionym do stosowania wszystkich środków egzekucyjnych, z wyjątkiem egzekucji z nieruchomości, w egzekucji administracyjnej należności pieniężnych, dla których ustalania lub określania i pobierania jest ów organ. Regulacja ta, pomimo pozornej jednoznaczności, kryje w sobie wiele pułapek.

Przede wszystkim mowa jest o gminie posiadającej status miasta, a pojęcie to nie pokrywa się w pełni z pojęciem miasta na prawach powiatu, jego zakres jest o wiele szerszy i nawiązuje do nieformalnego podziału na gminy miejskie i wiejskie. Gminą miejską (o statusie miasta) jest ta gmina, która swoim terytorium obejmuje wyłącznie miasto w jego granicach administracyjnych - w chwili obecnej istnieją w Polsce 302 jednostki samorządu terytorialnego o takim charakterze, w tym 66 miast na prawach powiatu².

Analizowany przepis wskazuje, że organem egzekucyjnym jest „właściwy” organ gminy o statusie miasta. Stosowanie do dalszej części przepisu jest on organem egzekucyjnym

12. http://eteryt.stat.gov.pl/eteryt/raporty/WebRaportZestawienie. aspx, [dostęp: 03.05.2018].

13. Ustawa z dnia 8 marca 1990 r. o samorządzie gminnym (Dz. U. z 2018 r. poz. 994 z późn. zm.), zwana dalej u.s.g.

14. Ustawa z dnia 24 listopada 1995 r. o zmianie zakresu działania niektórych miast oraz o miejskich strefach usług publicznych (Dz. U. z 1998 r. Nr 133, poz. 872). obowiązków, do których ustalenia i pobierania jest właściwy. Przyjęte rozwiązanie koresponduje z całokształtem zadań jakie pełnią organy wykonawcze jednostek samorządu terytorialnego w zakresie stosowania prawa i czuwania nad wykonaniem prawa. Pamiętajmy, że obowiązki pieniężne nakładane są w znacznej większości w postaci decyzji administracyjnych, a jak wynika z art. 39 ust. 1 ustawy o samorządzie gminnym ${ }^{13}$, decyzje w indywidualnych sprawach z zakresu administracji publicznej wydaje wójt, o ile przepisy szczególne nie stanowią inaczej. W przypadku miasta na prawach powiatu właściwym organem gminy o statusie miasta jest oczywiście prezydent miasta.

Kategorycznie należy podkreślić, że organ wykonawczy nie każdej gminy o statusie miasta czy miasta na prawach powiatu będzie występował w postępowaniu egzekucyjnym jako organ egzekucyjny. Gmina taka musi zostać wymieniona w przepisach odrębnych, przy czym sama ustawa nie wskazuje, o jakich regulacjach mowa i gdzie ich poszukiwać. Ustalenie, które gminy miał na myśli prawodawca, wymaga uprzedniego odnalezienia się w zawiłościach prawnych wynikłych na tle reformy administracji publicznej schyłku XX wieku i odtworzenia instytucji samorządu terytorialnego. Przepis art. 19 § 2 odsyła do nieobowiązującej już ustawy o zmianie zakresu działania niektórych miast oraz o miejskich strefach usług publicznych ${ }^{14}$, a tak naprawdę do dodanego do niej załącznika zawierającego listę 46 miast. Należy pamiętać, że na nocy art. 87 ustawy Przepisy wprowadzające

Miasto. Pamięć i Przyszłość 3/2 (2018) ISSN 2543-621X 
ustawy reformujące administrację publiczną ${ }^{15}$, wskazującego zadania i odpowiadające im kompetencje przejęte przez gminy o statusie miasta na podstawie art. 2 ust. 4 ustawy z dnia 24 listopada 1995 r. o zmianie zakresu działania niektórych miast oraz o miejskich strefach usług publicznych (tj. możliwość występowania jako organ egzekucyjny na podstawie art. 19 $\S 2$ u.p.e.a.), stają się zadaniami i kompetencjami tych miast. Na przykładzie Dolnego Śląska możemy wskazać Legnice, Wałbrzych i Wrocław jako gminy o statusie miasta będące jednocześnie miastami na prawach powiatu, uprawnionymi do pełnienia roli organu egzekucyjnego w egzekucji administracyjnej.

Tak ustalone organy egzekucyjne mogą zajmować się egzekucją wyłącznie należności pieniężnych, dla których ustalania lub określania i pobierania są właściwe. Wynika z tego istotny wniosek - w przypadku art. 19 § 2 zawsze zachodzi tożsamość podmiotowa pomiędzy wierzycielem a organem egzekucyjnym. Poza tym, zgodnie z ogólną zasadą, organem egzekucyjnym w stosunku do należności pieniężnych gmin, które nie spełniają wymogów stawionych przez ten przepis, jest naczelnik urzędu skarbowego. Postanowienia te wskazują również na dwa rodzaje aktów administracyjnych, w obrębie których dokonuje się konkretyzacja obowiązku pieniężnego - akty konstytutywne i akty deklaratoryjne. Pierwsze z nich, akty konstytutywne (ustalające), cechuje charakter twórczy, kreują stosunek prawny (np. obowiązek o charakterze pieniężnym), który to wynika

Miasto. Pamięć i Przyszłość 3/2 (2018) ISSN 2543-621X 71 z mocy aktu administracyjnego i obowiązuje od momentu wprowadzenia aktu do obrotu prawnego ${ }^{16}$. Natomiast akty deklaratoryjne (określające), potwierdzają skutki prawne wynikające wprost z ustawy, "odmrażają" je, i to z mocą wsteczną, tj. od momentu, w którym zaczął obowiązywać dany akt normatywny ${ }^{17}$. Odnosząc się do samych obowiązków pieniężnych, u.p.e.a w art. 2 wskazuje, jakiego rodzaju należności pieniężne podlegają egzekucji w postępowaniu administracyjnym wykonawczym. Obowiązki nakładane, pobierane i ewentualnie egzekwowane przez miasto na prawach powiatu to np. podatki lokalne (np. podatek od nieruchomości) czy kary administracyjne (kara za zajęcie pasa drogowego bez wymaganej zgody).

Dopuszczalność podjęcia i prowadzenia postępowania egzekucyjnego w administracji wymaga, oprócz istnienia właściwości rzeczowej organu egzekucyjnego, posiadania przezeń właściwości miejscowej. Zagadnienie właściwości posiada kardynalne znaczenie w postępowaniu egzekucyjnym w administracji, ponieważ w związku z art. 18 u.p.e.a ma w nim zastosowanie art. 19 Kodeksu postępowania administracyjnego ${ }^{18}$, statuujący konieczność przestrzegania z urzędu właściwości (miejscowej i rzeczowej, instancyjnej) przez organy administracji publicznej. Brak właściwości organu, do którego złożono wniosek o wszczęcie postępowania

15. Ustawa z dnia 13 października 1998 r. Przepisy wprowadzające ustawy reformujące administrację publiczną (Dz. U. z 2016 r. poz. 2260).

16. J. Zimmermann, Prawo administracyjne, Warszawa 2016, s. 376.

17. Tamże, s. 376.

18. Ustawa z dnia 14 czerwca 1960 r. - Kodeks postępowania administracyjnego (Dz. U. z 2018 r. poz. 149 z późn. zm.) zwana dalej k.p.a. 
egzekucyjnego, kreuje zatem konieczność przekazania wniosku do organu właściwego na podstawie art. 65 k.p.a. w związku z art. 18 u.p.e.a.. ${ }^{19}$. W związku z interesującym nas art. 19 $\S 2$ pojawił się istotny dylemat, dotyczący zaprezentowanego twierdzenia na temat właściwości, który znalazł swój finał w uchwale Naczelnego Sądu Administracyjnego ${ }^{20}$. W wyniku rozbieżności w orzecznictwie sądów administracyjnych Prezes NSA skierował do składu 7 sędziów NSA pytanie o następującej treści: „Czy właściwość rzeczowa gminnego organu egzekucyjnego, o której mowa w art. 19 § 2 u.p.e.a., przy egzekucji należności pieniężnych jest właściwością bezwzględną decydującą o jego kompetencji do prowadzenia egzekucji, czy też właściwość tego organu w wyżej wskazanym zakresie uzależniona jest raczej od jego właściwości miejscowej ustalanej w oparciu o art. 22 § 2 i 3 u.p.e.a?". Pamiętając, że właściwość miejscowa to zdolność prawna organu do stosowania środków przymusu na obszarze określonej jednostki podziału terytorialnego kraju, a organy egzekucyjne wymienione w art. 19 § 2 u.p.e.a. nie obejmują zakresem swojej właściwości terytorium całego państwa (gdyż jest ich wyłącznie 46). Budzi to uzasadnione wątpliwości w przedmiocie ustalenia właściwego organu egzekucyjnego i ewentualnego bezwzględnego charakteru przepisów art. 19 § 2. Skład sędziowski wyjaśnił, że regulacja art. 19 § 2 u.p.e.a. nie określa w sposób wyłączny właściwości organu egzekucyjnego, będącego właściwym organem gminy o statusie

19. Wyrok NSA z dnia 24 listopada 1998 r., III SA 918/97.

20. Uchwała NSA z dnia 8 grudnia 2014 r., II FPS 5/14.

21. Rozporządzenie Ministra Finansów z dnia 30 grudnia 2015 r. w sprawie postępowania wierzycieli należności pieniężnych (Dz. U. z 2017 r. poz. 1483). miasta wymienionej w odrębnych przepisach oraz gminy wchodzącej w skład powiatu warszawskiego i wymaga ponadto uwzględnienia przepisów wyznaczających właściwość miejscową. Przenosząc te twierdzenia na badany grunt, prezydent miasta na prawach powiatu będzie organem egzekucyjnym jedynie wtedy, gdy posiadać będzie właściwość miejscową ustaloną zgodnie z art. 22 § 2-4. u.p.e.a. Kiedy miejsce zamieszkania lub siedziby zobowiązanego znajduje się na obszarze miasta na prawach powiatu, ewentualnie ma on miejsce zamieszkania lub siedziby na terenie państwa członkowskiego lub państwa trzeciego (gdyż w takiej sytuacji organ egzekucyjny jest organ będący jednocześnie wierzycielem, co ma miejsce w analizowanym przypadku), prezydent miasta staje się organem egzekucyjnym. Właściwość kształtuje się natomiast w odmienny sposób , gdy zobowiązany zamieszkuje lub ma siedzibę, bądź też znany przed wszczęciem egzekucji majątek zobowiązanego lub większa jego część, znajduje się na terenie działania innej gminy niż ta jednostka samorządu terytorialnego, która ustaliła lub określiła dochodzoną należność. W takiej sytuacji organem wykonawczym zostaje naczelnik urzędu skarbowego.

Zaprezentowana przez uchwałę NSA wykładnia prawa znalazła swoje widoczne odbicie w przepisach prawa powszechnie obowiązującego. Do kwestii tej odnosi się rozporządzenie Ministra Finansów w sprawie postępowania wierzycieli należności pieniężnych²1, wyraźnie podkreślając w § 11, że jeżeli wierzyciel będący

Miasto. Pamięć i Przyszłość 3/2 (2018) ISSN 2543-621X 
jednocześnie organem egzekucyjnym, o którym mowa w art. 19 § 2 ustawy, nie jest właściwy ze względu na miejsce zamieszkania lub siedzibę zobowiązanego, przekazuje tytuł wykonawczy do właściwego miejscowo naczelnika urzędu skarbowego celem prowadzenia postępowania egzekucyjnego.

Prezydent miasta jako organ egzekucyjny obowiązków pieniężnych dysponuje rozbudowanym katalogiem środków przymusu administracyjnego. Wyposażony został w możliwość wykorzystania każdego przewidzianego przez ustawę środka egzekucyjnego, za wyjątkiem egzekucji z nieruchomości. Zgodnie z art. 1a pkt 12 lit. a środkami tymi są: egzekucja z pieniędzy, z wynagrodzenia za pracę, ze świadczeń z zaopatrzenia emerytalnego oraz ubezpieczenia społecznego, a także z renty socjalnej, z rachunków bankowych, z innych wierzytelności pieniężnych, z praw z instrumentów finansowych w rozumieniu przepisów o obrocie instrumentami finansowymi, zapisanych na rachunku papierów wartościowych lub innym rachunku, oraz z wierzytelności z rachunku pieniężnego służącego do obsługi takich rachunków, z papierów wartościowych niezapisanych na rachunku papierów wartościowych, $z$ weksla, z autorskich praw majątkowych i praw pokrewnych oraz z praw własności przemysłowej, z udziału w spółce z ograniczoną odpowiedzialnością, z pozostałych praw majątkowych oraz z ruchomości. W sytuacji, gdy organ wykonawczy gminy o statusie miasta, będący jednocześnie wierzycielem, nie jest w stanie osiągnąć postulowanego przez

Miasto. Pamięć i Przyszłość 3/2 (2018) ISSN 2543-621X prawo efektu, wykorzystując dostępne mu narzędzia egzekucyjne, pojawia się konieczność wystawienia jako wierzyciel dalszego tytułu wykonawczego (art. 26 c u.p.e.a.) i skierowania go do naczelnika urzędu skarbowego jako jedynego podmiotu mogącego stosować egzekucję z nieruchomości.

Aby podkreślić znaczenie regulacji art. 19 § 2 u.p.e.a. dla egzekucji obowiązków pieniężnych prowadzonych przez prezydentów miast na prawach powiatu, zasadnym staje się sięgnięcie do statystyk, które dobitnie obrazują wykorzystanie badanej regulacji. Delegatura Najwyższej Izby Kontroli w Kielcach wydała w maju 2009 r. Informację o wynikach kontroli efektywności egzekucji administracyjnej podatków i opłat, dla których ustalania lub określania i pobierania właściwy jest organ gminy²2. Informacja ta dotyczy poruszanej w niniejszym artykule problematyki. Dokument zawiera dane zebrane podczas kontroli efektywności i skuteczności egzekucji administracyjnej obowiązków pieniężnych, prowadzonej w dniach od 19 maja do 15 grudnia 2008 r. w 30 jednostkach, tj. 15 urzędach miast wybranych spośród 47 miast, których prezydenci posiadają uprawnienia organu egzekucyjnego oraz 15 urzędach skarbowych w wybranych miastach. Badaniami kontrolnymi objęto lata 2006-2008 (30 kwietnia). Kontrole w urzędach miast przeprowadzono z punktu widzenia legalności, gospodarności i rzetelności, a w urzędach skarbowych - legalności, gospodarności, celowości i rzetelności. W wyniku

22. Najwyższa Izba Kontroli - delegatura w Kielcach, Informacja o wynikach kontroli efektywności egzekucji administracyjnej podatków i opłat, dla których ustalania lub określania i pobierania właściwy jest organ gminy, maj 2009. Przytoczone w tekście dane mają swoje źródło na stronach: 4, 5 i 38 Informacji. 
działań egzekucyjnych przez poddanych kontroli prezydentów miast wyegzekwowano 92,2 mln zł należności ze 116142 tytułów wykonawczych. Stanowiło to 92\% tytułów wystawionych w okresie objętym kontrolą, a wartościowo - 38 proc. kwoty z nich wynikającej. W badanym przedziale czasu prezydenci miast objętych kontrolą przekazali do urzędów skarbowych (w tym objętych kontrolą) 19979 tytułów wykonawczych na kwotę $29 \mathrm{mln}$ zł, z tego w związku ze zbiegiem egzekucji - 866 tytułów na kwotę 2,9 mln zł i ze względu na bezskuteczność egzekucji lub właściwość miejscową - 19113 tytułów na kwotę 26,1 mln zł. Wynikająca z przekazanych tytułów kwota stanowiła 12\% kwoty 243,5 mln zł objętej wszystkimi wystawionymi tytułami wykonawczymi. W wyniku podjętych działań egzekucyjnych urzędy skarbowe, w tym także objęte kontrolą NIK, wyegzekwowały zaległości w kwocie 6,3 mln zł. Stanowiło to 22\% kwoty objętej tytułami wykonawczymi przekazanymi przez prezydentów miast.

Powyższe dane pozwalają stwierdzić, że Prezydenci miast prowadzący egzekucję obowiązków pieniężnych we własnym zakresie są o wiele skuteczniejsi niż naczelnicy urzędów skarbowych, którym powierzono egzekucję takich należności. Wynika to z faktu egzekucji obowiązków leżących w zakresie realizowanych przez miasta zadań - za ich wykonanie miasto nie tylko jest odpowiedzialne, ale samo na nich zyskuje. Oczywiście zaprezentowane wyniki dotyczą okresu odległego o 10 lat i wymagają niewątpliwie powtórzenia, aczkolwiek wskazują na pewien znaczący trend. Może on stanowić asumpt do postulowania rozszerzenia zakresu zastosowania art. 19. § 2 u.p.e.a. (poprzez uczynienie z niego bezwzględnego wyznacznika właściwości czy umożliwienie wykorzystania przez szerszy katalog gmin) jako regulacji będącej relatywnie skuteczną podstawą egzekucji obowiązków pieniężnych. Niewątpliwie odciążyłoby to również naczelników urzędów skarbowych, wpływając pozytywnie na efektywność prowadzonych przez nich egzekucji.

Powracając do przykładu obowiązku o charakterze pieniężnym ustalanego, pobieranego oraz egzekwowanego przez prezydenta miasta, można wskazać tutaj karę administracyjną za zajęcie pasa drogowego drogi powiatowej bez uzyskania zgody zarządcy drogi (art. 40 ust. 12 ustawy o drogach publicznych)23. Konstrukcja ta znakomicie wkomponowuje się w ideę miasta na prawach powiatu jako jednostki samorządu terytorialnego będącej expressis verbis gminą, której organy realizują zadania przewidziane dla powiatu. W przypadku powiatu jako samodzielnego podmiotu, zarządcą drogi wymierzającym karę administracyjną w rzeczonym przedmiocie jest zarząd powiatu (art. 19 ust. 2 pkt. 3 u.d.p.). Podkreślmy również, że zarząd powiatu nie pełni w takim przypadku funkcji organu egzekucyjnego, gdyż zastosowania nie znajduje art. 19 § 2 u.p.e.a., a rola ta przypada naczelnikowi urzędu skarbowego jako organowi o kompetencji ogólnej. Odmiennie mają się sprawy w mieście na prawach powiatu. W jego granicach zarządcą wszystkich dróg 
publicznych (w tym powiatowych), z wyjątkiem autostrad i dróg ekspresowych, jest prezydent miasta (art. 19 ust. 5 u.d.p.). Jak już zostało powiedziane, posiada on kompetencję do nałożenia kary administracyjnej w formie decyzji konstytutywnej i, będąc właściwym organem gminy o statusie miasta, występuje w postępowaniu wykonawczym jako organ egzekucyjny nakładanego przez siebie obowiązku pieniężnego. Podjęcie postępowania egzekucyjnego nie jest jednak możliwe ad hoc. Nawiązując do rozważań poczynionych w części odnoszącej się do istoty tegoż postępowania, zaznaczyć trzeba, że zastosowanie przymusu administracyjnego dopuszczalne jest w ostateczności. Wyraźnie koresponduje ze stanowiskiem tym art. 40 ust. 13 u.d.p. Termin uiszczenia kary administracyjnej za zajęcie pasa drogowego bez wymaganego zezwolenia zarządcy drogi wynosi 14 dni od dnia, w którym decyzja ustalająca ich wysokość stała się ostateczna. Wynika z tego, że dopiero po upływie 14 dni możliwe jest podjęcie działań na poziomie stadium poprzedzającego postępowanie egzekucyjne.

\section{Prezydent miasta na prawach powiatu w kontekście pozostałych ról procesowych egzekucyjnego postępowania administracyjnego}

O ile regulacją wyróżniającą miasto na prawach powiatu spośród pozostałych jednostek samorządu terytorialnego niewątpliwie jest art. 19 § 2 u.p.e.a., to nie możemy tracić z oczy pozostałych unormowań, które odnoszą się do

Miasto. Pamięći Przyszłość 3/2 (2018) ISSN 2543-621X 75 interesującego nas podmiotu. Przede wszystkim prezydent miasta na prawach powiatu kompetentny jest do przyjmowania pozycji nie tylko organu egzekucyjnego należności pieniężnych. Obowiązki prawne nie sprowadzają się wyłącznie do kwestii zapłacenia określonej sumy pieniędzy, mogą bowiem przyjmować również inną, niepieniężną postać - znoszenia lub zaniechania albo wykonania jakiejś czynności. Również w stosunku do takiej formy obowiązku prezydent miasta zdolny jest do występowania w roli organu egzekucyjnego. Podstawę do tego tworzy art. 20 § 1 pkt 2 u.p.e.a, a zgodnie z jego treścią organem egzekucyjnym w zakresie egzekucji administracyjnej obowiązków o charakterze niepieniężnym jest właściwy organ jednostki samorządu terytorialnego w zakresie zadań własnych, zadań zleconych i zadań z zakresu administracji rządowej oraz obowiązków wynikających z decyzji i postanowień z zakresu administracji publicznej wydawanych przez samorządowe jednostki organizacyjne. Właściwym organem jednostki samorządu terytorialnego jest tu oczywiście prezydent miasta, co wynika z definicji legalnej zawartej w art. 1a pkt 14 u.p.e.a. (pod pojęciem właściwego organu jednostki samorządu terytorialnego rozumie się odpowiednio wójta, burmistrza, prezydenta miasta, starostę lub marszałka województwa).

Przenosząc te rozważania na grunt praktyczny, możemy wskazać jako przykład przymusowego wykonania obowiązku niepieniężnego egzekucję nakazu nauki wynikającego z ustawy Prawo oświatowe 24 przez prezydenta miasta

24. Ustawa z dnia 14 grudnia 2016 r. Prawo oświatowe (Dz. U. z 2018 r. poz. 650), zwana dalej p.o. 
na prawach powiatu. Zgodnie z art. 35 ust. 1 p.o. nauka jest obowiązkowa do ukończenia 18 roku życia. Obowiązek ten ciąży na każdej osobie fizycznej do momentu ukończenia 18 lat, natomiast jego początek jest uzależniony od zrealizowania obowiązku szkolnego (po którym następuje), polegającego w obecnych realiach na ukończeniu szkoły podstawowej.

Kolejnym z podstawowych podmiotów występujących w każdym postępowaniu egzekucyjnym jest wierzyciel, czyli ten kto jest uprawniony do domagania się wykonania lub zabezpieczenia obowiązku. Ustawa o postępowaniu egzekucyjnym w administracji w art. 5 § 1 reguluje kwestie ustalania, jakie podmioty wchodzące w skład struktury ustrojowej egzekutywy (a nawet spoza niej) pełnią funkcję wierzyciela. W interesującym nas zakresie istotne są wyłącznie dwa ujęte w tym artykule punkty, tj. 1 i 2. Zgodnie z pierwszym z nich, uprawnionym do żądania wykonania w drodze egzekucji administracyjnej obowiązków jest - w odniesieniu do obowiązków wynikających z decyzi lub postanowień organów administracji rządowej i organów jednostek samorządu terytorialnego - właściwy do orzekania organ I instancji. Z konstrukcji tej wynika, iż prezydent miasta na prawach powiatu jako organ wykonawczy uprawniony do wydawania decyzji w indywidualnych sprawach z zakresu administracji publicznej (art. 39 ust. 1 u.s.g.), a w ramach samego postępowania administracyjnego jurysdykcyjnego do wydawania postanowień (np. postanowienie o ukaraniu grzywną świadka, który bezpodstawnie odmówił składania zeznań), może zająć pozycję wierzyciela. Chodzi tu o decyzje nakładające obowiązki, wydawane zarówno w efekcie realizacji zadań gminy, jak i powierzonych jej zadań powiatu. Prezydent miasta wydaje także decyzje administracyjne w ramach zadań powiatu, ponieważ pełni funkcję starosty oraz zarządu powiatu, a to właśnie im ustawa o samorządzie powiatowym przydaje kompetencję do podejmowania decyzji w indywidualnych sprawach z zakresu administracji publicznej należących do właściwości powiatu (art. 38 ust. 1 u.s.p.). Nawet w przypadku odwołania się od takiego aktu administracyjnego i wydania w wyniku postępowania odwoławczego rozstrzygnięcia, które zastąpi w obrocie prawnym decyzję organu pierwszej instancji (decyzja utrzymująca w mocy decyzję pierwszej instancji czy decyzja merytorycznej organu drugiej instancji), wierzycielem nadal pozostaje prezydent miasta.

Druga regulacja, na podstawie której organ wykonawczy miasta na prawach powiatu występuje w roli wierzyciela, dotyczy obowiązków wynikających z mocy samego prawa. Jak stanowi art. 5 § 1 pkt 2 u.p.e.a., dla obowiązków wynikających z orzeczeń sądów lub innych organów albo bezpośrednio z przepisów prawa - organ lub instytucja bezpośrednio zainteresowana w wykonaniu przez zobowiązanego obowiązku albo powołana do czuwania nad wykonaniem obowiązku, a w przypadku braku takiej jednostki lub jej bezczynności - podmiot, na którego rzecz wydane zostało orzeczenie lub którego interesy prawne zostały naruszone w wyniku 
niewykonania obowiązku. Unormowanie to wymaga w pierwszej kolejności sięgnięcia do przepisów administracyjnego prawa materialnego i ustalenia, który z organów występujących w strukturze, odpowiedzialny jest za realizację (czuwanie nad ich wykonaniem, nadzór) określonych zadań. Dopiero w wyniku takiego zabiegu będzie można ustalić, czy dane obowiązki wynikające z mocy samego prawa mieszczą się w zakresie kompetencji organu wykonawczego gminy, powiatu albo starosty i w efekcie przypadają prezydentowi miasta na prawach powiatu.

Występowanie jednostki samorządu terytorialnego w administracyjnym postępowaniu egzekucyjnym w roli zobowiązanego wydaje się - przynajmniej z potocznego punktu widzenia - czymś niesłychanym, a wręcz niemożliwym. Źródła takiego spojrzenia należy poszukiwać w niejako automatycznym utożsamianiu zobowiązanego z podmiotem występującym poza strukturami administracji publicznej. Trudno jest sobie wyobrazić, że gmina czy miasto na prawach powiatu związane są koniecznością uiszczania, np. danin publicznych tak jak przeciętny człowiek, że też muszą uiszczać określone podatki25. Swoją drogą, odzwierciedla to prawidłowości występujące w praktyce, gdzie adresatami nakazów czy zakazów są zazwyczaj (a nawet w zasadniczej większości) jednostki - osoby fizyczne, a także jednostki organizacyjne, co bez wątpienia może wprowadzić pewien zamęt w rzeczywisty obraz sytuacji. Zwróćmy jednak uwagę na postanowienia ustaw samorządowych ${ }^{26}$, które wyraźnie wskazują na

Miasto. Pamięć i Przyszłość 3/2 (2018) ISSN 2543-621X dysponowanie przez gminę, powiat, miasto na prawach powiatu czy województwo osobowością prawną umożliwiającą nabywanie na własny rachunek praw i obowiązków, nie wykluczając obowiązków natury publicznoprawnej. W ramach przykładu można w tym miejscu nawiązać do ustawy o podatku od towarów i usług27, która pomimo szerokiego wyłączenia podmiotowego organów władzy publicznej spod obciążenia podatkiem VAT, zawartego w art. 15 ust. 6, nie zakazuje w sposób absolutny nakładania na nie tego podatku. Stąd, jeśli miasto na prawach powiatu zawiera w ramach prowadzonych przez siebie działalności gospodarczych umowy cywilnoprawne (nie działa w sferze imperium), staje się płatnikiem podatku od towarów i usług, który może podlegać ściągnięciu w trybie egzekucji administracyjnej.

\section{Zakończenie}

Pozycja procesowa prezydenta miasta - gdyż to on reprezentuje miasto na prawach powiatu w postępowaniu egzekucyjnym - kształtuje się w rozbudowany sposób. Regulacje ustawy egzekucyjnej umożliwiają mu przede wszystkim występowanie w roli dwóch najistotniejszych, obligatoryjnych podmiotów procedury wykonawczej - organu egzekucyjnego i wierzyciela. Prezydent miasta uprawniony jest do egzekwowania obowiązków pieniężnych z zastosowaniem niemalże wszystkich środków

25. Nie można jednak zapomnieć o szczególnej funkcji, jaką pełni administracja publiczna i wynikających z niej różnica w przepisach prawnych do niej stosowanych.

26. Patrz: art. 2 ust. 2 u.s.g., art. 2 ust. 2 u.s.p., art. 6 ust. 2 ustawy z dnia 5 czerwca 1998 r. o samorządzie województwa (Dz. U. 2018, poz. 913 z późn. zm.).

27. Ustawa z dnia 11 marca 2004 r. o podatku od towarów i usług (Dz. U. z 2018 r. poz. 62 z późn. zm.). 
egzekucyjnych, co stawia go w tej kwestii na drugim miejscu, zaraz za naczelnikiem urzędu skarbowego. Ta swoista konstrukcja jest elementem znamiennym, wyróżniającym miasto na prawach powiatu i kształtujących jego pozycję w egzekucyjnym postępowaniu administracyjnym odmiennie od innych gmin czy pozostałych jednostek samorządu terytorialnego. Prezydent miasta został umocowany także do egzekucji nakazów i zakazów niezwiązanych z kwestiami finansowymi, wynikających czy konkretyzowanych w ramach zadań podejmowanych przez miasto na prawach powiatu. Nie wypada również zapomnieć o statusie wierzyciela, który może przypaść organowi wykonawczemu miasta na prawach powiatu, zastrzec jednak należy, że w większości przypadków i tak pozycja ta pokrywa się z funkcją organu egzekucyjnego. Nie zwalnia to jednak z wymogu upomnienia zobowiązanego czy zainicjowania postępowania egzekucyjnego, jeśli obciążony obowiązkiem nie urzeczywistni dobrowolnie postanowień prawa. Ostatecznie nie można wykluczyć, że w procedurze wykonawczej miasto na prawach powiatu zajmie nietypową - ze względu na swoją pozycje i pełnione zadania - rolę zobowiązanego, przeciwko któremu stosowane będą środki egzekucyjne.

\section{Literatura:}

- B. Adamiak, J. Borkowski, Postępowanie administracyjne i sadowoadministracyjne, Warszawa 2017.

- E. Bojanowski, Wykonanie zastępcze w egzekucji administracyjnej, Warszawa 1975.

- z. Leoński, Egzekucja administracyjna świadczeń niepieniężnych, Warszawa 1968.

- Prawo administracyjne, red. J. Boć, Wrocław 2010.

- System Prawa Administracyjnego, Prawne formy działania administracji, t. 5, red. R. Hauser, Z. Niewiadomski, A. Wróbel, Warszawa 2013.

- J. Zimmermann, Prawo administracyjne, Warszawa 2016.

- http://eteryt.stat.gov.pl/eteryt/raporty/WebRaportZestawienie.aspx.

- Najwyższa Izba Kontroli - delegatura w Kielcach, Informacja o wynikach kontroli efektywności egzekucji administracyjnej podatków i opłat, dla których ustalania lub określania i pobierania właściwy jest organ gminy, maj 2009.

Miasto. Pamięć i Przyszłość 3/2 (2018) ISSN 2543-621X 